\title{
News of Islamic Blasphemy on the Websites of Kompas and Republika: A Critical Discourse Analysis
}

\section{Nuryadi, D. Suganda, N. Sunarni, and N. Darmayanti}

Literature Department, Faculty of Humanities, Padjadjaran University, Jalan Raya Bandung Sumedang KM. 21, Sumedang 45363, West Java, Indonesia

\section{Abstract}

This article presents the views of Kompas and Republika regarding the news of religious blasphemy committed by Basuki Tjahaja Purnama (BTP), the governor of Jakarta from 2014 to 2017. Kompas is considered to be close to Christians while Republika is considered to be close to Muslims. The objective of the study is to understand the views of Kompas and Republika in delivering news of Islamic religious

Corresponding Author: Nuryadi nuryadilinguistics.45bgr@ gmail.com

Received: 6 April 2018 Accepted: 3 May 2018

Published: 26 July 2018

Publishing services provided by Knowledge

(c) Nuryadi et al. This article is distributed under the terms of the Creative Commons

Attribution License, which permits unrestricted use and redistribution provided that the original author and source are credited.

Selection and Peer-review under the responsibility of the ISLLE 2017 Conference Committee. blasphemy through the use of language. The research method used in this study is a descriptive qualitative method using Van Dijk's CDA approach, which consists of text analysis, social cognition analysis, and social context analysis. The data analyzed are samples of religious blasphemy news obtained from the website of Kompas and Republika between September 2016 and April 2017, each media is taken randomly $15 \%$ of total news. The results of the analysis show that the website of Kompas has a tendency to say that BTP did not insult religion and the court process was not fair while the website of Republika has a tendency to say that BTP was blasphemous. Both media expressed their views by creating the meaning which refers to the view of each newspaper using macrostructure elements that involve news titles, topic development, and news structure development, and microstructure elements that involve the usage of syntactic, semantic, and rhetorical aspects.

Keywords: critical discourse analysis, Jakarta gubernatorial election, macrostructure, microstructure, religious blasphemy, van Dijk's theory of CDA

\section{Introduction}

In describing an event, the media does not simply relate the incident, it also incorporates its views into the news. Media is not a value-free channel, it is also the subject that constructs reality, complete with views, biases, and partiality. News does not always reflect reality. This means the media tries to influence the reader in the way they see an event. Readers are invited to see an event from the media's perspective. 
The news of religious blasphemy as supposedly reported by Basuki Tjahaja Purnama (BTP), governor of Jakarta from 2014 to 2017, colored the news in some media for several reasons. Firstly, BTP was a Christian governor, while most Jakartans are Muslims, some of whom refused to accept a non-Muslim governor. Secondly, the incident took place near to the election of the governor of Jakarta, so this could be a crucial factor in this case. Thirdly, the issue is also very sensitive to the people of Jakarta in particular, and Indonesians in general, in view of the problems of tribe, religion, and race among groups. Media owners may also have an interest for economic and political reasons. Kompas and Republika are national media that have many readers; Kompas is considered to be close to Christians while Republika is considered to be close to Muslims. This study aims to understand the views of Kompas and Republika in cases of religious blasphemy in connection with BTP.

\section{Literature Review}

\subsection{Hegemony news in the media}

News contains media owners' opinions on important events happening in the community. This means that the attitude, views, judgments, stances, and partiality of media related to an event that is being talked about in the community can be known through the media. Raising an event as news means that the journalists or editors of the media are expressing their attitudes, views, judgments, stances, and partiality in relation to an important event that has become hot news in the community. Such media attitudes, views, and judgments can either support or oppose an event occurring in society.

The ideological theory of Althuser emphasizes how dominant groups control other groups that are weaker. According to the hegemonic theory of Antonio Gramsci, media can be a means of a group establishing its position and demeaning other groups. The hegemonic theory emphasizes that in society there is a fight or competition to win public acceptance because the social experience of the subordinate groups is different from that of the dominant group. Therefore, it is necessary for the dominant group to spread its ideology so that its existence in the society is accepted without resistance. One of the key strategies in hegemony is common sense [1].

Through hegemony, the ideology of the dominant group can be disseminated, and values and beliefs can be transmitted. The advantage of hegemony is that it can create certain ways of thinking or discourses that are considered true, while other discourses are wrong. The media can be a means by which values or discourses are disseminated and absorbed into the minds of audiences and become a shared consensus. In the 
production of the news, the process takes place in a subtle way so that what happens and is reported by the media appears to be a truth, logical, and is not to be questioned.

Political news always attracts audiences or readers because it directly or indirectly affects people's lives. The partiality of the media appears firmly and manifestly in political news compared to other news because it involves the spread of the values and ideology held by the media. News in the media is essentially a subjective process of constructing reality. Likewise, the political news does not fully reflect what actually happened but rather its tendency not to be objective. Political news delivered by media is not merely information but is the result of constructing reality so that it can contain media's own interests; therefore, the news is not neutral.

\subsection{Discourse analysis}

According to Fairclough [2] discourse is the use of language seen as a form of social practice, and discourse analysis is an analysis of how text functions in sociocultural practice. Halliday [3] gives a new perspective that language must also be seen from the perspective of its function not only its form. A critical linguist whose opinion pioneered the critical language study we know as critical discourse analysis (CDA). Fairclough points out that power and ideology are reflected in the language used. Fairclough [4] also states that in modern society, power is achieved through an ideology that is specifically done through the language used. CDA is an analysis aimed at seeing the use of language critically through linguistic aspects.

According to Van Djik [5], a text consists of three parts: macrostructures, superstructures, and microstructures. Macrostructure is a global meaning of a text that can be understood through its topic. Topics of discourses are represented in one or more sentences that are the main ideas or the ideas of the subject of discourse. Van Djik [5] refers to a topic as a semantic macrostructure. This is because when talking about a topic or theme in the text, we will be dealing with meaning and reference.

A superstructure is a structure used to describe schemata, in which the topic or global content of the news is inserted. This superstructure organizes topics by arranging sentences or news units in the order or hierarchy desired. According to Van Djik [5], a superstructure is a number of categories of news schemes or parts that build a news scheme that is summary and story. A summary consists of headlines and leads. This scheme element is considered an important element. Titles and leads generally show the theme that media wants to show in the news.

A lead contains an introduction before going to the full story while the story is a whole news content consisting of two parts. The first part is the event situation and 
the second is the comment displayed in the text [6]. Eriyanto further explained that the course of events consists of the main story and background that support the event. The background is used to give context so that it is clear when the news is presented to the audience or readers. The comments describe the parties who comment verbally and then conclusions are given by journalists.

According to van Dijk, a superstructure is a unified whole that will be followed by other parts of the news. What is disclosed in leads will be followed and supported by the news scheme. A schematic is a strategy to support a particular topic with a certain order or sequence. A schematic emphasizes which parts should take precedence as strategies to hide or show important information. Parts that are considered not important are usually placed at the end of the news text. Briefly, the elements of discourse according to van Dijk can be described as follows.

TABLE 1: Elements of discosure.

\begin{tabular}{|c|c|c|}
\hline Discourse Structure & Observed Element & Element \\
\hline MacroStructure & $\begin{array}{l}\text { THEMATIC } \\
\text { Theme or topic that is developed in } \\
\text { a text }\end{array}$ & Topic \\
\hline Superstructure & $\begin{array}{l}\text { SCHEMATIC } \\
\text { How structure of text schemes }\end{array}$ & Scheme \\
\hline \multirow[t]{4}{*}{ Microstructure } & $\begin{array}{l}\text { SEMANTICS } \\
\text { Meaning intended in the text such } \\
\text { as giving detail or explicit in a side } \\
\text { and reducing another side }\end{array}$ & $\begin{array}{l}\text { Background, detail, intention, } \\
\text { presupposition, nominalization }\end{array}$ \\
\hline & $\begin{array}{l}\text { SYNTAX } \\
\text { Form of sentenced chosen }\end{array}$ & $\begin{array}{l}\text { Form of sentenced chosen, } \\
\text { coherency, pronoun }\end{array}$ \\
\hline & $\begin{array}{l}\text { STYLISTIC } \\
\text { Word choice used in the text }\end{array}$ & Lexicon \\
\hline & $\begin{array}{l}\text { RHETORIC } \\
\text { How meaning is intended in a text }\end{array}$ & Figure, Metaphor, Expression \\
\hline
\end{tabular}

\section{Methods}

This study uses a qualitative research method that produces descriptive data with the approach of CDA [7-9]. Data are analyzed using the CDA theory of Van Djik [5] on macrostructure, superstructure, and microstructure. The macrostructure is analyzed to find out the theme of the news (thematic) and the superstructure is analyzed to find out how the news scheme is compiled (schematic). Meanwhile, microstructure analysis is conducted to find out semantic, syntactic, stylistic, and rhetorical aspects. At the level of social cognition, data that are analyzed are the process of production and consumption of text that involves the cognition of individual authors or journalists by 
conducting interviews. Meanwhile, at the level of social context, the analysis is done through a literature study and historical tracing. The data that are analyzed are samples of religious blasphemy on the Kompas and Republika websites supposedly committed by BTP between September 2016 and April 2017, each of media is randomly taken nineteen news as data. Kompas and Republika's websites are chosen as the object of research because cases of religious blasphemy have a wide impact on society and are reported in many national media.

\section{Results}

\subsection{Macro structure}

\subsubsection{Titles of news}

Based on the analysis of 19 news titles on the Kompas website, there are several themes that are interesting to discuss and are distinguished as follows: (1) BTP, (2) the action, (3) the judicial process. The action is the delivery of a speech in Kepulauan Seribu, a district of Jakarta, and the judicial process is the process of his speech in court. The Kompas website tends to present news advantageously from the perspective of BTP, the action, and the judicial process.

In relation to BTP, three out of five news titles tend to look positively and only one news tends to look negatively. The three news titles that tend to be advantageous are: (1) Reported to Bawaslu because of Quoting from Holly Book, This is Response from Ahok, (2) Testimony of Gus Soleh on Ahok Built Pesantren in Belitung Timur, (3) Gus Nuril: This Removes Stigma that Ahok does not Appreciate the Ulema. While two news titles that tend to be disadvantageous is (1) The Muhammadiyah Youth Leaders Report Ahok to the Police, and (2) Conducting Study, This is MUI's Opinion about Ahok Statement.

In relation to the actions, three news titles relate the case of religious blasphemy to the election of Jakarta's governor: (1) The Case of Religious Defamation is Called to Ending Ahok in the Gubernatorial Election of DKI; (2) Indonesia Council of Ulema Invites the Community to Stop the Politicization of Religion in the Gubernatorial Election of DKI 2017; (3) Religion Expert: Religiousness Opinion and Attitudes of Indonesia Council of Ulema Triggers the Bigger Problem.

There is one news title that tries to establish the meaning that religious blasphemy is also committed by the adherents of Islamic religion to their religion as in the title of the news Chairman of PBNU: The Bombers Blasphemes Religion too, and one news title that tends to build the meaning that Pramuka Island's citizens felt that BTP's speech 
did not create a problem: The Case of Alleged Blasphemy by Ahok in the Eye of Pramuko Island's Citizens. But there are two news titles that tend to be disadvantageous to BTP as in the titles: (1) Linguists Call Ahok's Speech in Kepulauan Seribu Exit from Context; (2) Witness of the Language Experts Call The Contents of Ahok's Speech Contained Blasphemy.

Related to the judicial process, three news titles tend to support BTP: (1) Determination of Ahok as Suspect is Colored by Differences of Expert opinion, (2) Ahok's Advocate says that Judicial Process because of Mass Pressure, (3) Rules of Religious Blasphemy, Bending Article but None Escoped. And only one news title tends to be neutral: Novel Becomes First Witness of Ahok Session.

Meanwhile, the Republika website builds a meaning that tends to be disadvantageous to BTP. When it comes to actions, five news titles tend to look negatively and only one news title tends to look positively. The five titles that tend to be negative are: (1) Habib Rizieq Says that Ahok Consistently Blaspheme Islamic Religion, This is the Argument; (2) Gus Dur's Eldest Daughter: Sorry I'm Not Supporting Ahok; (3) It is not because Ahok is Non-Muslim, but He Blasphemes the Qur'an, (4) These are Three Laws which are Violated by Ahok Related to Al Maidah; (5) Not MUI Enter Politics, but Ahok who Entered Religion Areo. While one news title tends to look positively: Linguistic Expert: There are Six Clauses in Ahok's insult Al-Maidah 51.

If it is related to the judicial process, six news titles tend to harm the actor: (1) Muhammadiyah's Youth: No Religion Blasphemer has been Sentenced Lightly; (2) Politician of PKS: The Judicial Demand to Ahok does not Fulfill the Sense of Justice; (3) Habib Novel hopes Ahok will soon be detained; (4) Muhammadiyah's Youth Hopes Expert Witness Ahok Can Be Independent; (5) Action of 212 is Finished, Public Must Guard Ahok Case in Prosecutor's Office; (6) Board of Police's Criminal and Detective Confiscate 15 Evidence of the Blasphemy of Ahok.

The Republika website also displays two news titles that tend to be advantageous to BTP: (1) Reason of Peter Says that Habib Rizieq is not Eligible to Be an Expert Witness of Ahok; (2) Chief of Police: There is a Hidden Destination in Demonstration 2 December.

Based on the analysis of news titles, the Kompas website tends to build the meaning that the case of religious blasphemy is advantageous to BTP. From the side of the actor, the Kompas website looks positively, and from the side of the action, the Kompas website relates the case to the gubernatorial election of Jakarta, while from the side of the legal process, the Kompas website supports BTP. Meanwhile, the Republika website tends to build a meaning that harms BTP; from the side of the actor, Republika's website looks negatively, and from the side of the action, Republika's website presumes there is a powerful intervention so that the legal process doesn't go fairly. 


\subsubsection{Theme of news}

Based on the thematic analysis, the themes that are chosen by the Kompas website are interesting to observe. The themes can be categorized into five. Firstly, the Kompas website links the theme of religious blasphemy with the election of Jakarta's governor. By developing the theme that the case of religious blasphemy is related to the Jakarta gubernatorial election, the Kompas website tends to build the meaning or lead people to believe that the case of religious blasphemy is exploited by others for political interests to lower their reputation or create a bad image so that people are reluctant to vote for him in the election and divert their support to other candidates [10]. This can be seen from the themes developed by the Kompas website: (1) Ahok trapped the politicization of certain group identity; (2) post-reformation, the case of religious blasphemy increased due to politicization; (3) political interest in Ahok case is considered more dominant; (4) a case of religious blasphemy called to tackle Ahok in the Jakarto election; (5) Ahok case is considered politicized.

Secondly, by developing the theme that the article used in the case of religious blasphemy is a rubber article, the Kompas website tends to develop the meaning that the judicial process is unfair; this means that anyone who has been identified as a suspect must be imprisoned because it is impossible to avoid the article being imposed. In other words, the article can be interpreted according to the appetite of law enforcers because the article is very flexible $[10,11]$. This can be seen from the themes developed by the Kompas website: (1) the religious blasphemy rule, the flexible article but no one escaped; (2) the articles presumed to be by BTP are considered easy to be politicized.

Thirdly, by developing the theme that religious blasphemy should be resolved through dialogue, the Kompas website tends to develop the meaning that a solution through the legal process is not appropriate since religion is something very personal. Moreover, it may also be intended to encourage the legal process to be discontinued because, at the international level, cases of religious blasphemy are unknown. This can be seen from the theme developed by the Kompas website: (1) Blasphemy should be resolved through dialogue, not a legal process.

Fourthly, by developing the theme that BTP's case is criminalized, the Kompas website tends to defend the meaning that BTP is innocent and a victim of the evil behavior of the other party. So the other party or political opponents are oblivious to criminalizing BTP. This can be seen from the theme developed by the Kompas website: (1) $A$ number of human rights activists claim that Ahok is a victim of criminalization.

Fifthly, by developing the theme that the legal process against BTP is because of mass pressure, the Kompas website tends to build the meaning that BTP is innocent 
but the masses want a case of religious blasphemy to be processed by law. This may be because there is another purpose. This can be seen from the theme developed by the Kompas website: (1) The judge denies the Ahok trial is influenced by mass pressure.

Sixth, by developing the theme that BTP does not insult Islam, the Kompas website tends to build the meaning that BTP does not mean to blaspheme against the religion of Islam, but there are other parties who misunderstand this meaning. BTP provides a lot of support for Islam, such as building an Islamic boarding school in Belitung, departure board of mosque to Mecca, and often contributes cattle on qurban day. This can be seen from the theme developed by the Kompas website: (1) Gus Soleh's testimony about BTP building an Islamic boarding school in Belitung Timur.

Meanwhile, the themes chosen by the Republika website are focused on the presumption of the intervention of power because the legal process of religious blasphemy is late to be processed. This is because of the closeness of BTP with the government that may affect the legal process so it should be guarded. This suspicion can be seen from the following themes: (1) December 2 action is very reasonable because of the slow and blunt law enforcement; (2) thousands of mass action requires low enforcement allegation of defamation of governor of DKI Jakarta; (3) legal process of alleged defamation of religion must remain guarded and controlled in the prosecutor's office.

After the reading of the prosecution, the suspicion seemed to be true that the themes developed reinforced the previous themes of intervening power in the judicial process or the closeness of the powers affecting the judicial process, such as (1) the actor of religious blasphemy is prosecuted for light sentences, $;$ (2) the Prosecutor's charge against BTP does not satisfy the sense of justice.

Suspicions of power intervention are also shown in other news themes. This theme was chosen after the central government did not dismiss BTP as governor of Jakarta even though he had been identified as a suspect. The prosecutors also did not arrest BTP as in the previous case; the theme is: (1) Habib Novel hoped that Ahok would be arrested soon.

The Republika website develops the theme that BTP insulted religion seriously, not just once but many times. The themes are: (1) The act of defomation committed by the defendant is consistent and repeatable; (2) Criminal Investigation Police confiscate 15 pieces of evidence in case of blasphemy; (3) People who denounce religion need to be taken action; (4) ICMI assessed that BTP violated three laws related to the statement of Surah al-Maidah article 51; (5) not MUI entering the political sphere, but the Governor of DKI BTP who entered the religious domain. 
There are six reasons that are built into the theme of the news. Firstly, the Kompas website tends to build the meaning that the articles are rubber articles that are applicable to the appetite of the law enforcers. Secondly, the legal process was carried out because of massive pressure since the case rolled in the community. Thirdly, religious blasphemy is unknown in the international legal system because of its abstract nature. Fourthly, the Kompas website cites the claim that a case of religious blasphemy should be resolved through dialogue, not judicial process. Fifthly, BTP is a victim of criminalization. Sixth, denial if BTP defames Islam.

Based on the analysis of news themes, the Kompas website tends to build the meaning that BTP substantively is not fair, because there is public pressure to influence law enforcers to bring the case of religious blasphemy to the court. Meanwhile, Republika's website tends to build the meaning that BTP seriously insulted religion so the legal process must go on fairly and law enforcers should not be influenced by the closeness of BTP with the government.

\subsection{Schematic of news}

Based on the schematic analysis, the news schemes are arranged like an inverted pyramid, where detailed information in the news is an elaboration of the themes that are presented in the news. The Kompas and Republika websites make relatively short news by quoting news sources from observers. The Kompas website quoted statements from NGOs, human rights activists, political observers, government officials, and public figures while Republika's website quoted news sources from members of parliament, organization activists, law advisors, and protesters. The quoted news sources are harmonized to the attitudes and views of each media because although the source news is the same person, the news is different.

\subsection{Micro structure}

\subsubsection{Semantic aspect}

Based on the semantic analysis, the meaning built by the Kompas website supports its theme. From the analysis of the element of purpose, the Kompas website uses the words to ask, remind, affirm, and argue. The appeal by using the word to ask is made by PBNU, who asked all parties to stop politicizing any religions in the Jakarta gubernatorial elections 2017. The word to ask is also used to call the public to be careful about using religions in politics. Another element of purpose uses the words to affirm 
and to argue. These words are used by BTP to assert that it is not possible for him to insult the religion of Islam because his stepmother, his uncle, and his brother are Muslims. The word to deny is also used by BTP, to deny that he has insulted the holy book of the Quran.

The element of purpose can also be seen from the use of the word to hope conveyed by BTP's lawyer teams so that the judges can decide on the case that ensnares his client fairly, honestly, and transparently, free from public pressure. Another element of purpose can be seen from the use of the word to claim by lawyer teams to claim that one of the leaders of a civic organization will fight furiously to tackle Ahok as a candidate for governor.

Another element of purpose on the Kompas website can be seen from the use of the word to issue. The word is used to state that the case of religious blasphemy is used as a reason to issue BTP from the nomination for governor in the Jakarta election. This statement was made by a political observer, Arbi Sanit, who saw suspiciously that from the early stages of the case there was already strength shown by a certain group in society that attempted to remove BTP from the candidacy in the Jakarta election.

Meanwhile, the meaning built by the Republika website uses the elements of purpose, which is disadvantageous to BTP. The Republika website uses the words to assert, judge, insist, and prejudice to affirm the element of purpose. As Gus Dur's daughter said, Allisa asserted that she did not support BTP. The word to assert is also used to convey the purpose that the legal process against BTP must be guarded and controlled by the prosecutor's office. This word is used by the member of parliament Jazuli Juwaini. The element of purpose also uses the word to evaluate to support the rallies on December 2 , 2016, which were said to be reasonable because of the slow and dull law enforcement process. The element of intention also uses the word insistent conveyed by the MUI to declare its stand that refuses to revoke its issued letter. Meanwhile, the word to prejudice is used by the Leaders of Muhammadiyah Youth, North Sumatra who distrusted a great power that protected BTP as a defendant.

The Republika website also uses the element of intention with the word to ask directed at the government's leader and the head of the law enforcers to act quickly after BTP was sentenced to one year in prison with a two-year probation. Therefore, we ask the leaders of this country and the leaders of low enforcement agencies to act quickly with all their wisdom. This was said by the Chairman of Muhammadiyah Youth Affairs (North Sumatra), Basir Hasibuan, who was shocked by the prosecution of the state prosecutor who was considered light by saying that the lawsuit was a new thing for the actor of religious blasphemy since it was previously demanded higher. 
Another element of purpose used by the Republika website is the word to affirm. Nevertheless, Jozuli affirms the alleged blosphemy of Basuki Tjahajo Purnama (Ahok) that becomes the demands of the action must be guarded and controlled at the prosecutor's office. The word to affirm is used to express the attitude to guarding and controlling the case of religious blasphemy at the prosecutor's level. This is because there is a suspicion of power interference.

Another element of purpose used is the word to evaluate in the sentence they evaluate, the action of December 2 nd is very reasonable because of the slow and dull law enforcement. The Republika website quotes the National Movement Command Guard Al Maidah. Quoting the above statement, Republika's website agrees with the action of December 2, 2016, because the law enforcement of religious blasphemy is slow.

Another element of intention used by Republika's website is the word to argue in the sentence Alwi Shihab argues, the Police should take legal action against the case of defomation of the Qur'an by the Governor of Jakarta, Basuki Tjahaja Purnama alias Ahok. Through such statements, Republika's website encourages or helps police officers to take legal action in cases of religious blasphemy.

Another element of purpose used by Republika's website is the word to tolerate in the sentence Religious blasphemer should not be tolerated, so that it is not to be a bad precedent and no one dares to defame religion. The statement was made by Alwi $\mathrm{S}$

hahab, a historian. Through such statements, Republika's website encourages or helps police officers to take legal action in cases of religious blasphemy.

Another element of purpose used by Republika's website is the words to insist on or stond firm in the MUI's sentence insisting on its stance and refusing to remove the issued letter. Through such statements, Republika's website encourages or helps police officers to take legal action in cases of religious blasphemy.

The presupposition contained in the news texts on the Kompas website is in the sentence Choirul Anam previously explained, in establishing the status of the suspect, there should be two elements to be met in article 156 a KHUP. The word should in this sentence presupposes that the determination of the suspect status by the police only to fulfill one party. In other words, through this presupposition, the Kompas website builds the meaning that BTP does not fulfill rules as a suspect.

Another presupposition on the Kompas website is that the democracy in Jakarta's gubernatorial election has died. The use of certain phrases in this sentence suggests that in Jakarta's elections there is no democracy anymore and there is no freedom given to the people because the candidate is defeated by a case of religious blasphemy and not by a candidate's competence. This means that the Jakarta elections 
are controlled by certain parties on behalf of the majority who impose their will on minorities.

\subsubsection{Syntactic aspect}

Based on the syntactic analysis, there are some interesting things to explain. In terms of the coherency of sentences, there is conditional coherency. If this is not controlled, it will destroy the joints of our nation's diversity. This is said by the Chairman of the Institute for Human Resource Studies and Development at PBNU who asked the candidates for governors and deputy governors to be careful not to say things that have the potential to attack their opponent or themselves because the stakes are very high, i.e. the diversity of the nation.

Conditional coherency also exists in the sentence If not anticipated, the condition can destroy the joint development of nationality that has been confirmed by the founders of the state. This was said by the Islamic teacher at Abdurrahman Wahid Soko Tunggal Islamic boarding school, Nuril Arifin while attending the National Islamic Studying event and the 44th anniversary of PDI-P in Lenteng Agung, South Jakarta. Through this coherency, he recalled that accusations of infidelity can destroy the joints of nationality, or in other words, the stakes are very high, i.e. the diversity of the nation.

The next coherency is the coherency of denial with the conjunction words but and yet. This was done when the mob urged that BTP should be detained, but the Kompas website stated that the detention of BTP could only be authorized by the investigator. The public urged that Ahok is detained immediately. However, Asep considers detaining a person is the authority of the investigator. Through such coherency, the Kompas website aims to give a view or a reminder that detention of a suspect is not because of pressure but is at the discretion of the investigators.

Coherency of denial is also used to comment on the base of the legal process. According to Choirul Anam, Senior Advisor of the Human Rights Working Group (HRWG), in general in the case of religious blasphemy, the police uses the logic of feelings of the offense not materially deeds that become the reference. However, the goal shifts out of the religious context and law enforcement in the context of politics. Through the denial of coherency, the Kompas website tends to state that cases of religious blasphemy are politically used as political tools. This is to comment on the actions of the police in deciding the status of BTP as a suspect not based on the material of action but based on the offense or aspect of the feelings.

The coherency of Republika's website uses conditional coherence. This condition, according to the Head of Muhammadiyah Youth North Sumatra, Basir Hasibuan, if it is 
not addressed wisely will cause social upheaval in society, and provoke the emergence of other religious blasphemy. This was said to comment on law prosecutions that are considered light and it is feared will trigger a similar case. Through this coherency, the Republika website sees the law prosecution of the blasphemy as light and it implicitly disagrees with it.

Another coherency that the Republika website uses is cause-result: it could have emerged the thought that there is a blasphemy of Islam let us use Islamic law because our low has been ridden the interests of the ruler. This coherency quotes the Chairman of Muhammadiyah Youth North Sumatra, Basir Hasibuan, after a fairly light law prosecution that could have an impact on the emergence of distrust and uncertainty in the minds of the public against the professionalism of law enforcers. Through this coherency, the Republika website agrees that there is another interest in the legal process.

Another conditional coherency used by the Republika website is If action is not taken, people will think the government is really silent. The statement was made by Jakarta's historian Alwi Shahab. Through this coherency, the Republika website agrees that fairly light law prosecution of religious blasphemy causes prejudice in society, and there is power intervention in this case.

The coherency of Republika's website uses the coherence of denial, Jakarta Governor Basuki Tjahaja Purnama (Ahok) who enters religious territory that is not his religion. This statement was made by the Deputy Secretary General of Ulema Council of Indonesia (MUI), Tengku Zulkarnain. Through this coherency, the Republika website agrees that BTP entered the religious territory of others, which should not be done.

\subsubsection{Stylistic aspect}

Based on the lexicon analysis, among the lexicons used by the Kompas websites are to consider, politicize, religious politicized, irregular, and tackle. The word to consider, according to $\mathrm{KBBI}$ or the Indonesian Dictionary [12], means to view as or to argue. This word is used by the Kompas website to mention the actions taken by BTP when he made a working visit to Kepulauan Seribu on September 27, 2016. Previous/y, many people considered BTP's remarks at the time the governor of Jakarta had degraded the religious teachings when he made a working visit to Kepulauan Seribu on September 27, 2016. By using the word to consider, the Kompas website takes the view that BTP did not blaspheme against religion.

The next lexicon that is used is politicized. This word is used by the Kompas website citing Gus Soleh, the Islamic teacher of Tebu Ireng Islamic Boarding School who came 
to the winning house of BTP to give testimony regarding what was done by BTP when becoming regent of East Belitung. Gus Soleh said this because he was not convinced that BTP was being blasphemous because, according to Gus Soleh, BTP's family was so kind in helping the community, both Muslim and non-Muslim. The meaning of the word politicized is the same as the politicization of making the situation related to political [12]. Through the use of the word politicized, the Kompas website expressed his view that the case of blasphemy is related to the election of Jakarta's governor.

The next lexicon used is politicization. This word is used by the Kompas website to quote the political observer from the University of Indonesia, Arbi Sanit, who saw the oddity of the BTP case from the beginning process conducted by the police. According to Arbi Sanit, the politicization of religion is also thick in the case of blasphemy. It is based on the mass action that can make law enforcers feel threatened. According to KBBI [12], politicization means making circumstances (actions, ideas) political or related to politics. Through the use of the word politicized, the Kompas website states its view in the case of religious blasphemy.'The next lexicon used is to tackle. This word is used by the Kompas website to quote BTP's lawyer, Trimoelja D Soerjadi when reading the defense memo at the North Jakarta District Court. In fact, he said, one of the leaders of social organizations claims to fight furiously to tackle Ahok becoming governor of Jakarta. This was based on the mass pressure that filled the streets of the capital protocol of Jakarta, which resulted in a very fast legal process. According to KBBI [12] to tackle means hinder or drop the career of others. Through the use of the word tackle, the Kompas website states its view that the case of blasphemy is used to tackle the incumbent.

Meanwhile, the Republika website also uses some lexicons to express its view. The first lexicon used by Republika's website is to be mocked. He assumes that, if the leader of this country is not quick to behove, there will be enormous consequences when the law in the case of religious persecution is mocked. This was revealed by the Chairman of Muhammadiyah Youth of North Sumatra, Basir Hasibuan. According to KBBI [12], the word mocked means the work is not done seriously. The word mocked is used to comment on religious defamation case that is considered light enough. Law enforcers are considered not to seriously enforce the law and play a role in blasphemy. Through the use of the word mocked, the Republika website expressed its view that cases of blasphemy are mocked.

The lexicons used by the Republika website are weird and not true. It's weird, the blasphemy case that caused the reaction of the people in Indonesia and even predicted millions of people took to the streets, only demanded two years trial, this is not true. This sentence was uttered by Nasir Jamil, a member of the House of Representatives 
at the Parliament Complex, Senayan, Jakarta, responding to the law prosecution of a defamation case that was considered quite light. According to KBBI [12], weird means unusual we see, hear, etc., while not true means should not [12] The law prosecution in religious blasphemy is considered unusual, or not suitable for the law. Through the use of this lexicon, the Republika website agrees that law prosecution in religious blasphemy is inconsistent with the same case before.

The lexicons used by Republika's website are racist and cowardly. In his clarification, Ahok actually names only those who are racist and cowardly using Al Maidah's as a political tool. According to $\mathrm{KBBI}$ [12], racist means in judgment based on ethnicity, whereas cowardly (2005, p. 524) means fear. The words were expressed by Rizieq imitating BTP's clarification on a private TV. Rizieq said that BTP did not give up after the incident in Kepulauan Seribu. Through the use of this lexicon, Republika's website agrees that BTP has not been blasphemous only once.

Another lexicon used by Republika's website is SARA. And this is not all related to SARA (ethnicity, religion, race, groups). This was said by Jazuli Juwaini, a member of the House of Representatives, to affirm that this was a legal case and not a political one. In Indonesia, the words that make up the acronym SARA are very sensitive because they can trigger widespread conflict and hostility in the society. Through the use of this lexicon, Republika's website agrees that the case of religious defamation is a legal case and is not related to SARA.

The lexicon used by Republika's website is dangerous. Because of this (harassment of the Qur'an) is very dangerous. According to KBBI [12], dangerous means contains hazards that can bring misery so one must be careful. The blasphemy of religion is said to be dangerous because it can lead to conflict or hostilities that have a widespread impact on society. Through the use of the lexicon, the Republika website agrees that the act could have an adverse impact on the community.

\section{Conclusion}

Based on the results of the analysis, the Kompas website tends to build the meaning that the case of religious blasphemy has a close relationship with the election of the governor of Jakarta. In other words, the religious defamation case is used to defeat or eliminate BTP in the election of the governor of Jakarta. The speech delivered in Kepulauan Seribu did not intend to insult religion, and therefore he should be set free. Meanwhile, the Republika website tries to build the meaning that BTP did commit religious blasphemy and his speech at Kepulauan Seribu is not the first time he defamed religion. Therefore, he must be processed legally in the court. The meanings that are 
built by each media are formed by developing a theme or meaning that refers to the view of each media by utilizing elements of discourse in the form of macrostructures that include the use of titles and theme development, and microstructures that include the use of syntactic, semantic, stylistic, and rhetorical aspects.

\section{References}

[1] Eriyanto: Analisis wacana: pengantar analisis teks media [Discourse analysis: introduction to media text analysis]. Yogyakarta: LKIS; 2001.

[2] Fairclough N: Language and power. London: Longman; 1998.

[3] Halliday MAK: An introduction to functional grammar. New York: Oxford University Press Inc; 2004.

[4] Fairclough N: Critical discourse analysis: the critical study of language. London: Longman; 1995.

[5] Van Dijk TA: Macrostructures : An interdisciplinary study of global structures in discourse, interaction, and cognition. Hillsdale : Lawrence Erlbaum; 1980.

[6] Eriyanto: Analisis framing : konstruksi, ideologi, dan politik media [Framing analysis: construction, ideology, and media politics]. Yogyakarta: LkiS; 2002.

[7] Creswell JW: Research design: qualitative, quantitative and mixed method approaches. California: SAGE Publication; 2014.

[8] Djajasudarma FT, Elvi C: Metodologi dan strategi penelitian linguistik [Methodology and strategy of linguistic research]. Bandung: Universitas Padjadjaran; 2017.

[9] Wodak R, Michael M: Method research in critical discourse analysis. London : Sage Publication; 2001.

[10] Fairclough N: Media discourse. London: Edward Arnold; 1995.

[11] Sobur A: Analisis teks media : suatu pengantar untuk analsiis wacana, semiotik, dan analisis framing [Media text analysis: an introduction to analytical discourse, semiotics, and framing analysis]. Bandung : Remaja Rosdakarya; 2006.

[12] KBBI. KBBI daring [Internet]. 2016 [cited 1 January 2017]. Available from: https:// kbbi.kemdikbud.go.id/. 